BRESM 80201

\title{
Tyrosine hydroxylase mRNA-containing neurons in the medial amygdaloid nucleus and the reticular nucleus of the thalamus in the Syrian hamster
}

\author{
Stephen E. Asmus **, Sarah Winans Newman* \\ Department of Anatomy and Cell Biology, Medical Science Building II, University of Michigan, Ann Arbor, MI 48109-0616, USA
}

(Accepted 20 July 1993)

Key words: Catecholamine; Amygdala; Colchicine; In situ hybridization; Species specificity

\begin{abstract}
To confirm previous immunocytochemical findings in colchicine-treated Syrian hamsters, in situ hybridization was used to investigate the distribution of TH mRNA-containing cells in the medial amygdaloid nucleus (Me) and the thalamic reticular nucleus (Rt) of untreated hamsters. TH mRNA-producing neurons were observed in anterior and posterior Me and throughout Rt, similar to the distribution of TH-immunostained cells in these areas of animals receiving colchicine. These data confirm that TH is normally produced in amygdaloid and thalamic cell groups which lie outside the classical catecholamine systems.
\end{abstract}

The distribution of catecholamine-containing cells in the central nervous system, as originally described using formaldehyde-induced histofluorescence ${ }^{5}$, has been confirmed by the immunocytochemical localization of tyrosine hydroxylase $(\mathrm{TH})^{17}$, the rate-limiting enzyme in catecholamine biosynthesis. Recently, however, TH-producing neurons have been reported in numerous brain regions and in a variety of mammalian species that are outside the classically-described catecholaminergic systems $8,10,11,14,16,18,23,24,26,28,29,40,41,44$. One such area is the medial amygdaloid nucleus $(\mathrm{Me})$ of the Syrian hamster (Mesocricetus auratus) $)^{1,2,6,42}$. This nucleus is a major relay area for incoming olfactory and vomeronasal signals ${ }^{22,38}$ and projects to the medial preoptic area and hypothalamus ${ }^{12}$. While studying the amygdaloid TH neurons, Asmus et al. ${ }^{2}$ also observed a limited number of $\mathrm{TH}$-immunostained cells in the reticular nucleus of the thalamus ( $\mathrm{Rt}$ ) in the hamster, another region that lies outside of the previously-described catecholaminergic cell groups. The $\mathrm{Rt}$ is a thin sheet of GABAergic neurons ${ }^{7,19}$ located at the lateral boundary of the dorsal thalamus that receives collat- eral inputs from traversing thalamocortical and corticothalamic fibers $^{20}$.

Although a limited number of $\mathrm{TH}$-immunoreactive neurons are observed in $\mathrm{Me}^{2,6,42}$ and $\mathrm{Rt}$ (unpublished observations) of hamsters not treated with colchicine, the full extent of TH-immunostained cells in these regions are observed only in animals that have received intracerebroventricular injections of colchicine ${ }^{1,2}$, an axoplasmic transport inhibitor ${ }^{4}$ commonly used to enhance immunostaining of various substances. However, this drug has been shown to induce de novo expression of mRNAs for various neuropeptides ${ }^{3,25,36}$. To determine whether the immunocytochemical findings in the hamster were an artifact of the drug treatment, we examined the distribution of TH mRNA-containing cells in Me and Rt of untreated hamsters using in situ hybridization.

Four adult male Syrian hamsters were anesthetized with sodium $(\mathrm{Na})$ pentobarbital $(15 \mathrm{mg} / 100 \mathrm{~g}$ b.wt., i.p.) and perfused transcardially with isotonic saline containing $0.1 \% \mathrm{Na}$ nitrite, followed by $250 \mathrm{ml}$ of $4 \%$ paraformaldehyde in $0.1 \mathrm{M} \mathrm{Na}$ phosphate buffer $(\mathrm{pH}$

\footnotetext{
* Corresponding author. Fax: (1) (313) 763-1166.

** Present address: Department of Neurosciences, Case Western Reserve University, 10900 Euclid Ave., Cleveland, OH 44106-4975, USA.
} 


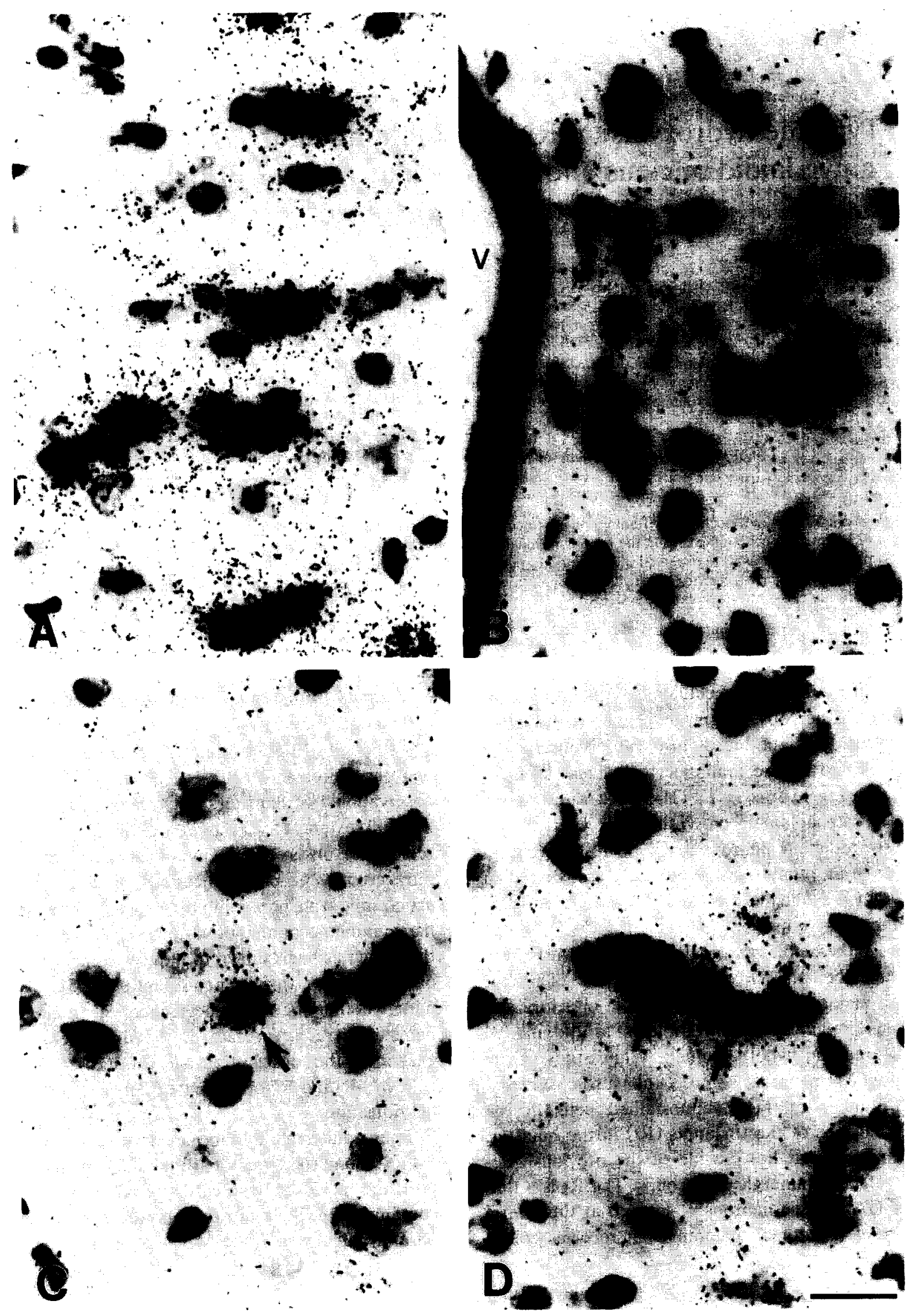


7.4). Brains were removed and postfixed for $1 \mathrm{~h}$ in the perfusion fixative. An additional brain was removed from an anesthetized, non-perfused hamster. All brains were frozen in isopentane cooled with liquid nitrogen and stored at $-80^{\circ} \mathrm{C}$. Coronal brain sections $(12 \mu \mathrm{m})$ were cut on a cryostat at -18 to $-20^{\circ} \mathrm{C}$, thaw-mounted onto poly-L-lysine-coated slides, and stored at $-80^{\circ} \mathrm{C}$.

On the day of hybridization, sections from the unperfused brain were fixed in $4 \%$ paraformaldehyde in $0.1 \mathrm{M}$ PBS for $15 \mathrm{~min}$. All sections were placed in proteinase $\mathrm{K}(10 \mu \mathrm{g} / \mathrm{ml}$ perfused tissue; $2 \mu \mathrm{g} / \mathrm{ml}$ immersion-fixed tissue) in TE buffer ( $100 \mathrm{mM}$ Tris, 50 $\mathrm{mM}$ EDTA, $\mathrm{pH} 8.0$ ) for $30 \mathrm{~min}$ at $37^{\circ} \mathrm{C}$, immersed in $0.0025 \%$ acetic anhydride in $0.1 \mathrm{M}$ triethanolamine (pH 8.0) for $10 \mathrm{~min}$ at room temperature, and then dehydrated in alcohols prior to hybridization.

$\mathrm{T} 3$ polymerase was used to transcribe ${ }^{35} \mathrm{~S}$-labeled antisense cRNA probes from a $1.2 \mathrm{~kb}$ cDNA insert cloned into the EcoRI restriction site of the $\operatorname{pBS}(+/-)$ transcription vector (Stratagene). This cDNA clone (RR 1.2, generously provided by Dr. D. Chikaraishi) corresponds to nucleotides $14-1165$ of the rat $\mathrm{TH}$ gene sequence ${ }^{15}$. The cRNA probe was purified using NENSORB 20 Nucleic Acid Purification Cartridges (NEN/Dupont), and the specific activity was determined $\left(2.1-2.3 \times 10^{5} \mathrm{cpm} / \mu \mathrm{l}\right)$. The probe was diluted to an activity of $1.7 \times 10^{4} \mathrm{cpm} / \mu \mathrm{l}$ with hybridization buffer containing $50 \%$ formamide, $10 \mathrm{mM}$ Tris (pH 8.0), 1 mM EDTA, $300 \mathrm{mM} \mathrm{NaCl}, 10 \%$ dextran sulfate, $1 \times$ Denhardt's, and $100 \mathrm{mM}$ dithiothreitol (DTT). This hybridization solution was applied to the sections and covered with a glass coverslip. After a $16 \mathrm{~h}$ incubation at $56^{\circ} \mathrm{C}$, the slides were washed and coverslips removed in $2 \times$ SSC. Sections were then incubated in RNase $\mathrm{A}(20 \mu \mathrm{g} / \mathrm{ml})$ for $30 \mathrm{~min}$ at $37^{\circ} \mathrm{C}$ and washed in decreasing concentrations of SSC containing $1 \mathrm{mM}$ DTT at $56^{\circ} \mathrm{C}(2 \times, 1 \times$ for $10 \mathrm{~min}$ each; $0.5 \times$ for $60 \mathrm{~min}$ ), after which sections were dehydrated in alcohols.

The slides were dipped in photographic emulsion (Kodak NTB-2), stored at $4^{\circ} \mathrm{C}$ for $14-16$ days, and developed in Kodak D-19 developer. After counterstaining with hematoxylin and eosin, the sections were dehydrated, cleared with xylene and coverslipped with Permount.

Control experiments were conducted to determine the specificity of the TH probe. Some sections were treated as described above but were incubated with
RNase A $(20 \mu \mathrm{g} / \mathrm{ml})$ for $30 \mathrm{~min}$ at $37^{\circ} \mathrm{C}$ prior to hybridization with labeled probe to digest tissue RNA. Other sections were processed as described above but incubated with hybridization solution containing $1.7 \times$ $10^{4} \mathrm{cpm} / \mu 1$ of sense-strand (non-complementary) probe synthesized with T7 polymerase to test for specificity of base pairing between TH mRNA and probe rather than binding due to physical properties. Finally, the distribution of TH mRNA-containing cells was compared to the distribution of $\mathrm{TH}$-immunoreactive cells.

Sections through the amygdala were sampled at 24 $\mu \mathrm{m}$ intervals in all five brains. These sections included all but the most rostral levels of the thalamus. Therefore, a few sections through the rostral thalamus and, as positive controls, a number through the substantia nigra were also hybridized. To quantify the number of labeled cells per section in $\mathrm{Me}$, four sections through anterior Me were examined in two of the five brains. Using brightfield illumination, the number of reduced silver grains over individual cells was counted manually at $500 \times$ magnification. A cell was considered labeled if the number of grains over its cytoplasm was $3 \times$ greater than that over adjacent, cell-sized areas of neuropil or over neurons in other brain regions that do not contain TH mRNA or protein ${ }^{32}$. To compare the number of TH mRNA-labeled cells in Me in this study with the number of TH-immunoreactive neurons observed previously in colchicine-treated hamsters ${ }^{1}$, the average number of labeled cells per section was multiplied by 3.33 to correct for differences in tissue thickness (12 $\mu \mathrm{m}$ vs. $40 \mu \mathrm{m})$.

During our prior studies $^{1,2}$, the brains of 20 colchicine-treated and 3 untreated hamsters were used for TH immunocytochemistry. The protocols for colchicine administration $(200 \mu \mathrm{g})$, perfusion with $4 \%$ paraformaldehyde, and processing of the brains for immunocytochemistry with a monoclonal TH antibody (Incstar) were as previously described ${ }^{1}$.

Cells with dense clusters of grains overlying the cytoplasm were observed in the classically-described catecholaminergic cell groups of the midbrain (A9, A10; Fig. 1A) and hypothalamus (A11-A14; Fig. $1 B)^{5,17}$. In addition, the distribution of TH mRNA-containing cells in the hamster brain was identical to the pattern of TH immunostaining. No specific hybridization signal was observed in sections pretreated with RNase or incubated with the sense-strand probe. Based

Fig. 1. Photomicrographs of TH mRNA-containing cells in (A) substantia nigra, (B) paraventricular nucleus of the hypothalamus adjacent to the third ventricle (v), (C) medial amygdaloid nucleus (one labeled cell at arrow), and (D) reticular nucleus of the thalamus (two adjacent labeled cells at arrows). Bar $=20 \mu \mathrm{m}$. 
on these findings, the TH cRNA probe used in this study is concluded to hybridize specifically with $\mathrm{TH}$ mRNA.

In all brains, distinct groups of TH mRNA-containing cells were observed in both the amygdala and the thalamic reticular nucleus. In the amygdala, TH mRNA-producing cells were observed predominantly in the anterior and posterior regions of Me (Fig. 1C), while labeled cells were also scattered in the anterior amygdaloid area, the anterior, ventral portion of the central nucleus of the amygdala and in the intraamygdaloid bed nucleus of the stria terminalis. This distribution matches that observed with TH immunocytochemistry here and in previous studies ${ }^{1,2}$. The TH mRNA-producing cell groups in anterior and posterior Me were identical in location to the distribution of TH-immunostained cell groups in colchicine-treated hamsters, with the majority of labeled cells concentrated in the dorsal subdivisions of each of these areas. Furthermore, in two of the brains, the number of labeled cells per $12 \mu \mathrm{m}$ section through anterior $\mathrm{Me}$ ranged from $7-14$, with a mean of 10.4 . To estimate the number of TH-mRNA-containing cells present in a $40 \mu \mathrm{m}$ section, this mean was multiplied by 3.33 to yield a value of approximately 35 cells per section. Although well above background, the density of grains per labeled cell in Me generally was less than that observed in cells in the substantia nigra and the paraand periventricular hypothalamic nuclei (Fig. 1A,B).

A large number of TH mRNA-containing cells was also observed in Rt throughout its rostrocaudal and dorsoventral extent, with no apparent topographic distribution (Fig. 1D). Labeled cells in the posterior region of Rt were continuous ventromedially with the TH-producing cells of the zona incerta.

As reported previously ${ }^{1,2,6,42}$, a limited number of $\mathrm{TH}$-immunoreactive neurons were found in Me of untreated animals, and colchicine treatment dramatically increased this number. In contrast to the $\mathrm{TH}$ cells in $\mathrm{Me}$, colchicine treatment only slightly enhanced TH immunolabeling in Rt. In Rt of both treated and untreated brains, the TH-immunostained cells contained a faint light brown reaction product (Fig. 2A), compared to the intense black product seen in TH-immunostained neurons in $\mathrm{Me}$ (Fig. 2B) and other brain regions.

The distribution of TH mRNA-containing cells in Me and Rt observed with in situ hybridization in this

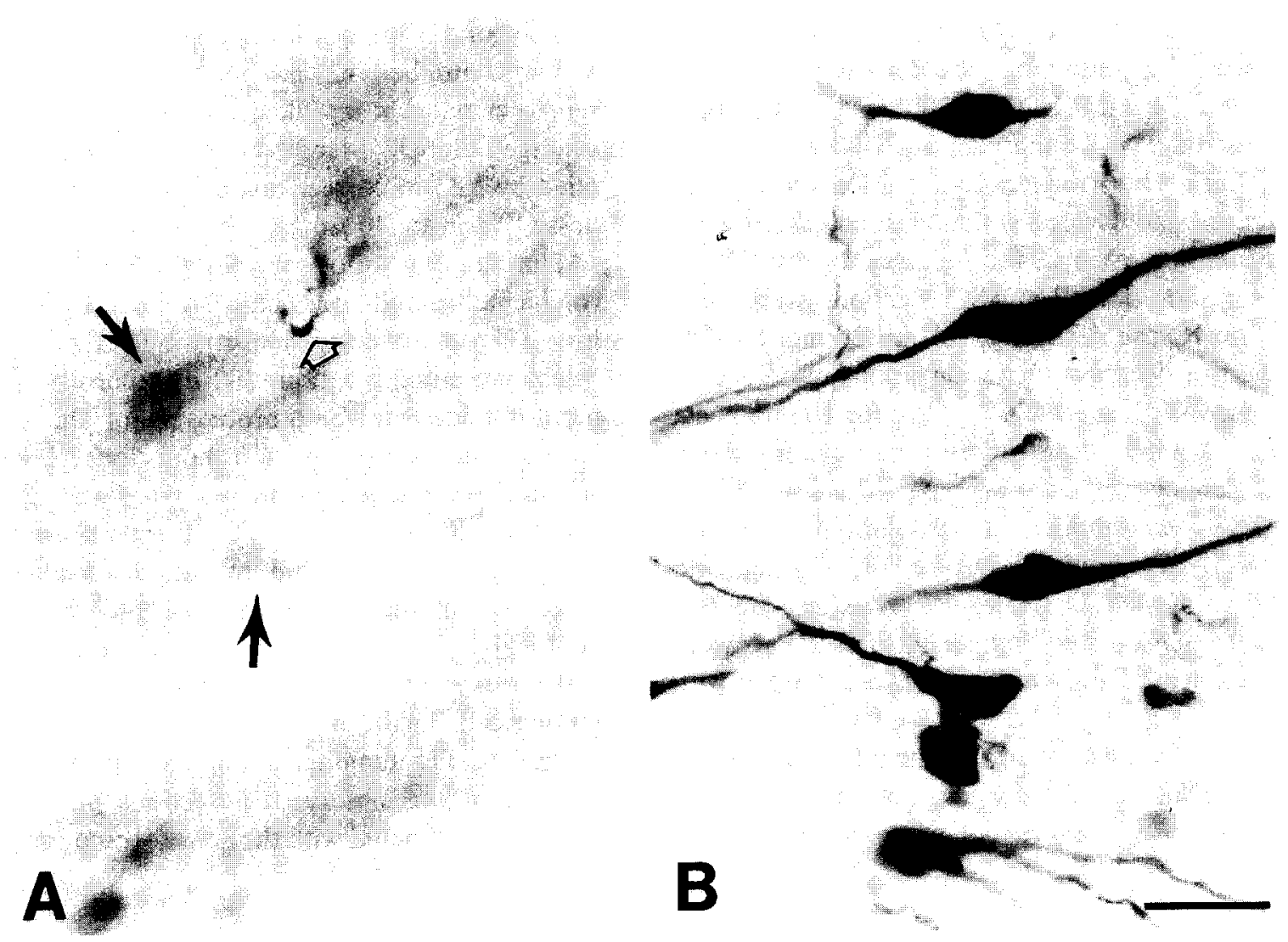

Fig. 2. Photomicrographs of TH-immunoreactive neurons in (A) reticular nucleus of the thalamus and (B) medial amygdaloid nucleus of colchicine-treated hamsters. Note the faint TH immunostaining in cells of the reticular thalamic nucleus (solid arrows) relative to the dark immunolabeling of a nearby TH-immunoreactive fiber (open arrow) and to $\mathrm{TH}$-labeled cells in the medial amygdaloid nucleus $(\mathrm{B})$. Bar $=20 \mu \mathrm{m}$. 
study was similar to that observed using TH immunocytochemistry in colchicine-treated hamsters ${ }^{1,2}$. Furthermore, after correcting for differences in section thickness, the number of TH mRNA-containing cells was equivalent to the average number of TH-immunostained neurons in sections through $\mathrm{Me}$ of animals receiving the drug ${ }^{1}$. These results support our previous assumption that colchicine administration enhances immunostaining by blocking axoplasmic transport rather than by inducing de novo synthesis of $\mathrm{TH}$ in the amygdala and thalamus of the hamster.

The observation of $\mathrm{TH}$ mRNA-containing cells in the hamster $\mathrm{Me}$ and $\mathrm{Rt}$ adds to a growing list of TH-producing cells that are located outside of the classically-described catecholaminergic systems, and this distribution is often species-specific $1,2,6,8,10,11,14,16,18,23,24,26,28,29,40-42,44$. The unique pattern of $\mathrm{TH}$ expression observed in the Syrian hamster may be due to species differences in the regulatory regions of the TH gene'.

In many of these novel $\mathrm{TH}$ cell groups, the final catecholamine being produced is not known. Previous studies in the hamster have shown that neither the amygdala nor the thalamus contain neurons immunostained for dopamine- $\beta$-hydroxylase or phenylethanolamine- $N$-methyltransferase ${ }^{2,42}$, enzymes that synthesize norepinephrine and epinephrine, respectively. Dopamine-immunostained neurons were observed in the posterior region of $\mathrm{Me}$, but not in anterior $\mathrm{Me}^{2}$ or in Rt (unpublished observations), suggesting that the $\mathrm{TH}$-producing cells in posterior $\mathrm{Me}$ synthesize dopamine. Whether the TH-containing cells in anterior Me and Rt produce aromatic amino acid decarboxylase (AADC), the enzyme that converts L-DOPA to dopamine, awaits further study. Several reports indicate that some TH-producing cells may not synthesize AADC and that the endproduct of $\mathrm{TH}$ cells lacking this enzyme may be L-DOPA ${ }^{23,31,43}$, which has been shown to be released in a transmitter-like fashion ${ }^{13.33}$.

At present, the functional significance of the species-specific TH mRNA-containing cells reported here is not known. The medial amygdaloid nucleus is a critical area in a neural circuit that processes chemosensory signals and gonadal hormonal information, both of which are essential for mating behavior in the male hamster ${ }^{37}$. Our previous studies indicate that many of the TH-producing neurons in Me may be influenced by gonadal steroids. A majority of $\mathrm{TH}$-immunostained neurons in the posterior subdivision of this nucleus also contained androgen receptors, and in anterior Me, although fewer TH-immunolabeled cells contained androgen receptors, the number of TH-im- munoreactive neurons declined after castration ${ }^{1}$. Thus, the function of the TH mRNA-containing cells observed in both parts of Me may be influenced by gonadal steroids, which are essential for both reproductive $^{35}$ and aggressive ${ }^{27}$ behaviors in the hamster.

The reticular thalamic nucleus receives information concerning a variety of sensory modalities via collateral inputs from thalamocortical and corticothalamic axons, and this nucleus projects to the same thalamic nuclei from which it receives input ${ }^{20}$. Based on this hodological and physiological evidence, Rt is believed to modulate the activity of thalamocortical neurons ${ }^{39}$. In the rat, the majority of neurons in this nucleus are GABAergic $^{7,19}$, and the cat Rt contains both GABA and somatostatin ${ }^{34}$. Preliminary results suggest that the hamster Rt also contains mRNA for glutamic acid decarboxylase (GAD) (unpublished observations), the enzyme which synthesizes GABA. The observation of TH mRNA-containing cells in the hamster Rt suggests that TH and GAD may be colocalized in Rt of this species. The coexistence of TH and GAD has been reported in other regions of the rat brain ${ }^{29}$. Thus, catecholamines, as well as GABA, may play a role in the modulation of thalamocortical signaling in the hamster.

However, although numerous cells in $\mathrm{Rt}$ were specifically labeled by the TH cRNA probe, TH immunocytochemistry in colchicine-treated as well as untreated hamsters resulted in extremely faint immunolabeling of cells in this nucleus compared to other THimmunostained cell groups. One explanation for this weak immunostaining is that the enzyme is rapidly transported out of the cell body. This is unlikely considering that these animals were given an axoplasmic transport inhibitor. Another possibility is that the cRNA probe used here is recognizing another mRNA similar in sequence to TH mRNA. This also appears unlikely due to the negative control results and to the observation of $\mathrm{TH}$-immunostained cells in this brain region. In this regard, the hamster does not appear to synthesize multiple isoforms of $\mathrm{TH}$ because Western blotting of hamster brain and adrenal revealed only a single band close in size to that of rat $\mathrm{TH}^{43}$. A more plausible explanation is that relatively little of the $\mathrm{TH}$ mRNA in these cells is translated into protein. The production of TH is known to be regulated at both the transcriptional and translational levels ${ }^{21,30}$. In conclusion, although TH mRNA is abundant in cells of the hamster Rt, they may produce little, if any, functional TH protein. Future studies should examine the synthesis of AADC, as well as the presence of L-DOPA or dopamine, in this brain region. 
The authors thank Dr. Dona Chikaraishi for providing the TH cDNA clone and the Molecular Biology and Morphology Cores of the Reproductive Sciences Program at the University of Michigan for excellent technical assistance, supported by 1-P30-HD-18258. This work was supported by NIH Grant NS20629 to S.W.N.

1 Asmus, S.E. and Newman, S.W., Tyrosine hydroxylase neurons in the male hamster chemosensory pathway contain androgen re ceptors and are influenced by gonadal hormones, J. Comp. Neurol., 331 (1993) 445-457.

2 Asmus, S.E., Kincaid, A.E. and Newman, S.W., A species-specific population of tyrosine hydroxylase-immunoreactive neurons in the medial amygdaloid nucleus of the Syrian hamster, Brain Res., 575 (1992) 199-207.

3 Cortes, R., Ceccatelli, S., Schalling, M. and Hökfelt, T., Differential effects of intracerebroventricular colchicine administration on the expression of mRNAs for neuropeptides and neurotransmitter enzymes, with special emphasis on galanin: an in situ hybridization study, Synapse, 6 (1990) 369-391.

4 Dahlstrom, A., Effect of colchicine on transport of amine storage granules in sympathetic nerves of rat, Eur. J. Pharmacol., 5 (1968) $111-113$

5 Dahlstrom, A. and Fuxe, K., Evidence for the existence of monoamine-containing neurons in the central nervous system. I. Demonstration of monoamines in the cell bodies of brain stem neurons, Acta Physiol. Scand., 62, Suppl. 232 (1964) 1-55.

6 Davis, B.J. and Macrides, F.M., Tyrosine hydroxylase immunoreactive neurons and fibers in the olfactory system of the hamster. J. Comp. Neurol., 214 (1983) 427-440.

7 De Biasi, S., Frassoni, C. and Spreafico, R., GABA immunoreactivity in the thalamic reticular nucleus of the rat. A light and electron microscopical study, Brain Res., 399 (1986) 143-147.

8 Dubach, M., Schmidt, R., Kunkel, D., Bowden, D.M., Martin, R. and German, D.C., Primate neostriatal neurons containing tyrosine hydroxylase: immunohistochemical evidence, Neurosci. Lett., 75 (1987) 205-210.

9 Gandelman, K.-Y., Coker, G.T., Moffat, M. and O'Malley, K.L., Species and regional differences in the expression of cell-type specific elements at the human and rat tyrosine hydroxylase gene loci, J. Neurochem., 55 (1990) 2149-2152.

10) Gaspar, P., Berger, B., Alvarez, C., Vigny A. and Henry, J.P., Catecholaminergic innervation of the septal area in man: immunocytochemical study using TH and DBH antibodies, J. Comp. Neurol., 241 (1985) 12-33.

11 Gaspar, P., Berger, B., Febvret, A., Vigny, A., Krieger-Poulet, M and Borri-Voltattorni, C., Tyrosine hydroxylase-immunoreactive neurons in the human cerebral cortex: a novel catecholaminergic group?, Neurosci. Lett., 80 (1987) 257-262.

12 Gomez, D.M. and Newman, S.W., Differential projections of the anterior and posterior regions of the medial amygdaloid nucleus in the Syrian hamster, J. Comp. Neurol, 317 (1992) 195-218.

13 Goshima, Y., Kubo, T. and Misu, Y., Transmitter-like release of endogenous 3,4-dihydroxyphenylalanine from rat striatal slices. $J$. Neurochem., 50 (1988) 1725-1730.

14 Gouras, G.K., Rance, N.E., Young, W.S. and Koliatsos, V.E., Tyrosine hydroxylase-containing neurons in the primate basal forebrain magnocellular complex, Brain Res., 584 (1992) 287-293.

15 Grima, B., Lamouroux, A., Blanot, F., Faucon Biquet, N. and Mallet, J., Complete coding sequence of rat tyrosine hydroxylase mRNA, Proc. Natl. Acad. Sci. USA, 82 (1985) 617-621.

16 Henderson, Z., A small proportion of cholinergic neurones in the nucleus basalis magnocellularis of ferret appear to stain positively for tyrosine hydroxylase, Brain Res., 412 (1987) 363-369.

17 Hökfelt, T., Martensson, R., Björklund, A., Kleinau, S. and Goldstein, M., Distributional maps of tyrosine-hydroxylase-immunoreactive neurons in the rat brain. In A. Björklund and T. Hökfelt (Eds.), Handbook of Chemical Neuroanatomy, Vol. 2, Classical Transmitters in the CNS, Part I, Elsevier, Amsterdam, 1984, pp. 277-379.

18 Hornung, J.-P., Tork, I. and De Tribolet, N., Morphology of tyrosine hydroxylase-immunoreactive neurons in the human cerebral cortex, Exp. Brain Res., 76 (1989) 12-20.
19 Houser, C.R., Vaughn, J.E., Barber, R.P. and Roberts, E., GABA neurons are the major cell type of the nucleus reticularis thalami, Brain Res., 200 (1980) 341-354.

20 Jones, E.G., The Thalamus, Plenum, New York, 1985.

21 Kaneda, N., Sasaoka, T., Kobayashi, K., Kiuchi, K., Nagatsu, I., Kurosawa, Y., Fujita, K., Yokoyama, M., Nomura, T., Katsuki, $M$. and Nagatsu, T., Tissue-specific and high-level expresson of the human tyrosine hydroxylase gene in transgenic mice, Neuron, 6 (1991) 583-594.

22 Kevetter, G.A. and Winans, S.S., Connections of the corticomedial amygdala in the golden hamster. II. Efferents of the "olfactory amygdala", J. Comp. Neurol., 197 (1981) 99-111.

23 Kitahama, K., Geffard, M., Okamura, H., Nagatsu, I., Mons, N. and Jouvet, M., Dopamine- and DOPA-immunoreactive neurons in the cat forebrain with reference to tyrosine hydroxylase-immunohistochemistry, Brain Res., 518 (1990) 83-94.

24 Kitahama, K., Okamura, H., Goldstein, M., Nagatsu, I., Berod, A. and Jouvet, M., A new group of tyrosine hydroxylase-immunoreactive neurons in the cat thalamus, Brain Res., 478 (1989) $156-160$

25 Kiyama, H. and Emson, P.C.. Colchicine-induced expression of proneurotensin mRNA in rat striatum and hypothalamus, $\mathrm{Mol}$. Brain Res., 9 (1991) 353-358.

26 Kohler, C., Everitt, B.J., Pearson, J. and Goldstein, M., Immunohistochemical evidence for a new group of catecholamine-containing neurons in the basal forebrain of the monkey, Neurosci. Lett., 37 (1983) 161-166.

27 Koolhaas, J.M., van den Brink, T.H.C., Roozendaal, B. and Boorsma, F., Medial amygdala and aggressive behavior: interaction between testosterone and vasopressin, Aggress. Behav., 16 (1990) 223-229.

28 Kordower, J.H., Sladek, J.R., Fiandaca, M.S., Bing, G. and Gash, D.M., Tyrosine hydroxylase-immunoreactive somata within the primate subfornical organ: species specificity, Brain Res., 461 (1988) 221-229.

29 Kosaka, T., Kosaka, K., Hataguchi, Y., Nagatsu, I., Wu, J.-Y. and Ottersen, O.P., Catecholaminergic neurons containing GABA-like and/or glutamic acid decarboxylase-like immunoreactivities in various brain regions of the rat, Exp. Brain Res., 66 (1987) $191-210$.

30 Leviel, V., Guibert, B., Mallet, J. and Faucon-Biguet, N., Induction of tyrosine hydroxylase in the rat substantia nigra by local injection of forskolin, J. Neurosci. Res., 30 (1991) 427-432.

31 Meister, B., Hökfelt, T., Steinbusch, H.W.M., Skagerberg, G.. Lindvall, O., Geffard, M., Joh, T.H., Cuello, A.C. and Goldstein, M., Do tyrosine hydroxylase-immunoreactive neurons in the ventrolateral arcuate nucleus produce dopamine or only L-DOPA?, J. Chem. Neuroanat., 1 (1988) 59-64.

32 Morrell, J.I., Rosenthal, M.F, McCabe, J.T., Harrington, C.A., Chikaraishi, D.M. and Pfaff, D.W., Tyrosine hydroxylase mRNA in the neurons of the tuberoinfundibular region and zona incerta examined after gonadal steroid hormone treatment, $\mathrm{Mol}$. Endocrinol, 3 (1989) 1426-1433.

33 Nakamura, S., Goshima, Y., Yue, J.L. and Misu, Y.. Transmitter-like basal and $\mathrm{K}^{+}$-evoked release of 3,4-dihydroxyphenylalanine from the striatum in conscious rats studied by microdialysis, $J$. Neurochem., 58 (1992) 270-275.

34 Oertel, W.H., Graybiel, A.M., Mugnaini, E., Elde, R.P., Schmechel, D.E. and Kopin, I.J., Coexistence of glutamic acid decarboxylase- and somatostatin-like immunoreactivity in neurons of the feline nucleus reticularis thalami, J. Neurosci.. 3 (1983) 1322-1332.

35 Powers, J.B., Bergondy, M.L. and Matochik, J.A., Male hamster sociosexual behaviors: effects of testosterone and its metabolites, Physiol. Behat., 35 (1985) 607-616.

36 Rethelyi, M., Mohapatra, N.K., Metz, C.B., Petrusz, P. and Lund, P.K., Colchicine enhances mRNAs encoding the precursor of calcitonin gene-related peptide in brainstem motoneurons, $\mathrm{Neu}$ roscience, 42 (1991) 531-539.

37 Sachs, B.D. and Meisel, R.L., The physiology of male sexual behavior. In E. Knobil and J. Neill (Eds.), The Physiology of Reproduction, Raven, New York, 1988, pp. 1393-1485. 
38 Scalia, F. and Winans, S.S., The differential projections of the olfactory bulb and accessory olfactory bulb in mammals, J. Comp. Neurol., 161 (1975) 31-56.

39 Steriade, M., Domich, L. and Oakson, G., Reticularis thalami neurons revisited: Activity changes during shifts in states of vigilance, J. Neurosci., 6 (1986) 68-81.

40 Tashiro, Y., Sugimoto, T., Hattori, T., Uemura, Y., Nagatsu, I., Kikuchi, H. and Mizuno, N., Tyrosine hydroxylase-like immunoreactive neurons in the striatum of the rat, Neurosci. Lett., 97 (1989) 6-10.

41 Torres, E.M., Rogers, D.C., Annett, L.E., Sirinathsinghji, D.J.S. and Dunnett, S.B., A novel population of tyrosine hydroxylase immunoreactive neurons in the basal forebrain of the common marmoset (Callithrix jacchus), Neurosci. Lett., 150 (1993) 29-32.
42 Vincent, S.R., Distributions of tyrosine hydroxylase-, dopamine$\beta$-hydroxylase-, and phenylethanolamine- $N$-methyltransferase-immunoreactive neurons in the brain of the hamster (Mesocricetus auratus), J. Comp. Neurol., 268 (1988) 584-599.

43 Vincent, S.R. and Hope, B.T., Tyrosine hydroxylase containing neurons lacking aromatic amino acid decarboxylase in the hamster brain, J. Comp. Neurol, 295 (1990) 290-298.

44 Wisniowski, L., Ridley, R.M., Baker, H.F. and Fine, A., Tyrosine hydroxylase-immunoreactive neurons in the nucleus basalis of the common marmoset (Callithrix jacchus), J. Comp. Neurol, 325 (1992) 379-387. 